\title{
Microbiological, epidemiological and clinical correlates of vaginal colonisation by Mobiluncus species
}

\author{
S L Hillier, C W Critchlow, C E Stevens, M C Roberts, P Wolner-Hanssen, D A Eschenbach, \\ K K Holmes
}

\begin{abstract}
The microbiological and epidemiological correlates of vaginal colonisation by Mobiluncus species were examined among randomly selected women attending a sexually transmitted disease (STD) clinic. Women positive for Trichomonas vaginalis were excluded. Mobiluncus spp. were detected by Gram stained vaginal smear in $21 \%$ of 633 STD clinic patients, including $53 \%$ of those with and $4 \%$ of those without bacterial vaginosis (BV), as diagnosed by clinical criteria. Gardnerella vaginalis and Mycoplasma hominis detected by vaginal culture and Mobiluncus detected by vaginal Gram stain were each independently associated with $\mathrm{BV}$ after adjusting by logistic regression for the presence of sexually transmitted disease pathogens, gravidity, parity and number of lifetime sexual partners ( $p<0.001$ for each organism). Bacterial vaginosis was negatively correlated with isolation of lactobacilli, yeast and herpes simplex virus. After adjusting for presence or absence of BV, women with Mobiluncus were more likely to harbour $G$ vaginalis (odds ratio $5 \cdot 6$, $95 \%$ confidence interval 1.6-19.5), $M$ hominis (OR 3·7, 95\% CI 2.0-7·0) and Neisseria gonorrhoeae (OR 2.9, 95\% CI 1.4-6.0) and less likely to harbour vaginal yeast (OR $0.4,95 \% \mathrm{CI} 0 \cdot 2-1 \cdot 0)$; were more likely to be black (OR $2 \cdot 7,95 \%$ CI
\end{abstract}

University of Washington, Department of Obstetrics and Gynecology

S L Hillier, P Wolner-Hanssen, D A Eschenbach

Department of Biostatistics

CW Critchlow

Department of Medicine

C E Stevens, K K Holmes

Department of Pathobiology

M C Roberts

Center for Aids and Sexually Transmitted Diseases at the Harborview Medical Center, Seattle, Washington

K K Holmes
1.5-4.6), and to have been pregnant (OR 1.8, $95 \%$ CI 1.1-3.1); but after the adjustment for BV, vaginal colonisation by Mobiluncus was not associated with symptoms of odour, abdominal pain, menstrual irregularities, or with adnexal tenderness. In summary, Mobiluncus, Gardnerella vaginalis and Mycoplasma hominis were independently associated with a clinical diagnosis of bacterial vaginosis, and Mobiluncus was further associated with the presence of $\mathrm{BV}$-associated microorganisms (M hominis and $G$ vaginalis), $\boldsymbol{N}$ gonorrhoeae, black race, and gravidity.

\section{Introduction}

There are currently two known species of the genus Mobiluncus: $M$ curtisii and $M$ mulieris. ${ }^{1}$ These organisms are extremely fastidious, requiring fresh moist media and extended anaerobic incubation for isolation. Because of the difficulty in isolating these organisms by culture, most researchers attempting to define the prevalence of this organism have used direct techniques such as Gram stain, wet smear, direct staining with monoclonal antibodies or DNA probes. For example, curved rods were detected in Gram stained smears of vaginal fluid by Spiegel $e t \mathrm{al}^{2}$ in $51 \%$ of 61 women with bacterial vaginosis (that is, nonspecific vaginitis), and by Cristiano et al ${ }^{3}$ in $39 \%$ of 163 women with bacterial vaginosis and $0.3 \%$ of women without bacterial vaginosis. Hallen et $a l^{4}$ detected Mobiluncus spp. with monoclonal antibodies in $20 \%$ of 455 women attending a sexually transmitted disease clinic, including $50 \%$ of the 107 women with $\mathrm{BV}$, while Roberts et al $^{5}$ detected Mobiluncus by Gram stain and DNA probe in $33 \%$ of 92 consecutive female STD clinic patients, including $68 \%$ of women with BV. Mobiluncus has been less highly associated with BV among pregnant women. Krohn ${ }^{6}$ reported finding Mobiluncus morphotypes by Gram stain in $28 \%$ of 122 pregnant women with BV compared with $3 \%$ of 471 pregnant women without clinical signs of BV.

Many questions remain concerning the ecology of Mobiluncus spp, including the factors responsible for 
vaginal colonisation and the clinical manifestations of vaginal colonisation with these organisms. Further, bacterial vaginosis, whether defined by the clinical criteria of Amsel, ${ }^{7}$ by Gram stain ${ }^{8}$ or simply by the presence of clue cells, has been associated with several symptoms, signs and laboratory findings, as well as with adnexal tenderness. ${ }^{9}$ It remains to be determined whether any of the several microorganisms associated with bacterial vaginosis including Mobiluncus spp, are associated with, or perhaps responsible for, particular symptoms, signs or laboratory abnormalities.

Thomason et al ${ }^{10}$ found that women whose vaginal fluid contained motile curved rods detected by wet mount had the clinical signs of bacterial vaginosis, and a ten-fold increased prevalence of vaginal colonisation by anaerobic Gram negative bacteria, as compared with women whose wet mount examination did not show curved rods. No studies to date have examined the associations of Mobiluncus spp with other vaginal or cervical pathogens. Thus it is uncertain whether the association of Mobiluncus with bacterial vaginosis is independent of its association with other microorganisms thought to be involved in this syndrome, or whether vaginal colonisation by Mobiluncus requires the presence of certain other organisms. Finally, the possible role of factors other than the presence of other organisms in predisposing to Mobiluncus colonisation warrants further study. Holst $e t a l^{11}$ have suggested that rectal colonisation may predispose to vaginal colonisation. Other risk factors have not yet been implicated.

In this study, the frequency of several vaginal and cervical pathogens was obtained among 633 consecutive randomly selected patients attending a Sexually Transmitted Disease (STD) clinic in Seattle. The prevalence of Mobiluncus by Gram stain and the association of this organism with bacterial vaginosis, with various demographic and behavioural risk factors, and with other genital microorganisms are described.

\section{Materials and methods}

Study population

Women presenting to the Harborview Medical Center, Seattle King County Department of Public Health Sexually Transmitted Disease (STD) Clinic were eligible for study if they were seeking care for the first time or for a new problem, were at least 16 years old, not pregnant, and had not received any antibiotics in the prior two weeks. The study clinician selected a sample of patients from among those waiting to be seen, using a table of random numbers. Women who were positive for $T$ vaginalis by wet mount or culture were excluded, leaving 633 eligible for study.
}

\section{Patient examination}

A standardised medical, gynaecological and sexual history was taken. The vulva, vagina and cervix were examined by colposcopy and the characteristics of any discharge were noted. The $\mathrm{pH}$ of the vaginal fluid was determined with $\mathrm{pH}$ indicator sticks (MCB Reagents, Gibbstown, JJ). A second smear of vaginal fluid was made with normal saline for observation by light microscopy for clue cells. Release of a "fishy" odour from vaginal fluid was tested by addition of $10 \% \mathrm{KOH}$. Women were diagnosed as having BV clinically if they had three of the four following criteria: homogeneous vaginal discharge, presence of clue cells in vaginal fluid, fishy odour after mixing vaginal fluid with $10 \%$ potassium hydroxide $(\mathrm{KOH})$, and a vaginal fluid $\mathrm{pH} \geq 4.7$. $^{9}$ Abdominal and bimanual pelvic examinations were also performed.

\section{Detection of Mobiluncus by Gram stain}

Vaginal Gram stains were evaluated by one of the authors for the presence of curved, Gram negative to Gram variable rods. The evaluator had no knowledge of the clinical findings of the patients. The ability of the evaluator to identify correctly Mobiluncus morphotypes in vaginal smears was confirmed by performing detailed vaginal cultures and direct DNA hybridisation assays on a subset of 103 consecutive vaginal specimens using methods previously described. ${ }^{5}$ Of these 103 specimens, Mobiluncus was detected by culture or DNA hybridisation with the whole chromosomal DNA probe in 26 of 31 cases that were positive by Gram stain, for a sensitivity of $84 \%$. The remaining 72 specimens were negative by culture, DNA hybridisation assay and Gram stain, giving a specificity and positive predictive value of $100 \%$ for detection by Gram stain.

\section{Detection of other microorganisms}

Vaginal or endocervical swab specimens for isolation of Neisseria gonorrhoeae, Trichomonas vaginalis, Mycoplasma hominis, Gardnerella vaginalis, Lactobacillus and Candida albicans were inoculated immediately onto the appropriate growth media as previously described. ${ }^{12}$ Endocervical specimens for Chlamydia trachomatis and herpes simplex virus (HSV) cultures were transported in tissue culture medium with antibiotics and stored at $4^{\circ} \mathrm{C}$ until inoculated (within 6 hours for HSV and cytomegalovirus and within 24 hours for $C$ trachomatis).

\section{Statistical methods}

Associations between Mobiluncus or BV and the presence of other pathogens or demographic variables were first identified by univariate analyses. These associations were measured using the odds ratio (OR) with the corresponding $P$ value based on the chi square test of whether the OR was equal to one (indicating no association). ${ }^{13}$ Approximate $95 \%$ 
Table 1 Association of selected organisms with bacterial vaginosis among a cohort of 633 women

\begin{tabular}{|c|c|c|c|c|c|c|}
\hline \multirow[b]{2}{*}{ Organism } & \multicolumn{2}{|c|}{ Bacterial vaginosis } & Univariate & \multirow[b]{2}{*}{$p$} & Multivariate ${ }^{\star}$ & \multirow[b]{2}{*}{$p$} \\
\hline & $\begin{array}{l}\text { Present } \\
=205\end{array}$ & $\begin{array}{l}\text { Absent } \\
n=428\end{array}$ & $O R(95 \% C I)$ & & $O R(95 \% C I)$ & \\
\hline $\begin{array}{l}\text { G. vaginalis } \\
\text { M. hominis } \\
\text { Lactobacillus } \\
\text { Mobiluncus } \\
\text { U. urealyticum } \\
\text { Yeast } \\
\text { C. trachomatis } \\
\text { N. gonorrhoeae } \\
\text { Herpes simplex virus } \\
\text { Cytomegalovirus }\end{array}$ & $\begin{array}{l}97 \% \\
82 \% \\
67 \% \\
53 \% \\
94 \% \\
12 \% \\
14 \% \\
16 \% \\
5 \% \\
10 \%\end{array}$ & $\begin{array}{r}58 \% \\
27 \% \\
87 \% \\
4 \% \\
84 \% \\
33 \% \\
15 \% \\
7 \% \\
11 \% \\
5 \%\end{array}$ & $\begin{array}{c}24 \cdot 3(10 \cdot 2,62 \cdot 1) \\
12 \cdot 2(7 \cdot 9,18 \cdot 9) \\
0 \cdot 3(0 \cdot 2,0 \cdot 5) \\
29 \cdot 7(16 \cdot 3,54 \cdot 7) \\
2 \cdot 9(1 \cdot 5,5 \cdot 7) \\
0.3(0 \cdot 2,0.5) \\
1 \cdot 0(0 \cdot 6,1 \cdot 6) \\
2 \cdot 5(1 \cdot 5,4 \cdot 4) \\
0.4(0 \cdot 2,0.9) \\
1.3(1.0,1 \cdot 8)\end{array}$ & $\begin{array}{c}<0.001 \\
<0.001 \\
<0.001 \\
<0.001 \\
<0.001 \\
<0.001 \\
0.85 \\
<0.001 \\
<0.02 \\
\quad 0.06\end{array}$ & $\begin{array}{c}11.9(4.4,31.8) \\
5.7(3.3,9.9) \\
0.5(0.3,0.8) \\
13.8(7.0,27.4) \\
0.6(0.2,0.6) \\
0.4(0.2,0.8) \\
0.6(0.3,1.2) \\
0.9(0.4,2.0) \\
0.3(0.1,0.7) \\
1.2(0.5,2.8)\end{array}$ & $\begin{array}{c}<0.001 \\
<0.001 \\
0.02 \\
<0.001 \\
0.4 \\
0.01 \\
0.19 \\
0.81 \\
0.01 \\
0.68\end{array}$ \\
\hline
\end{tabular}

^All organisms included in the model so that analysis of each in relation to bacterial vaginosis was adjusted for the presence of the other microorganisms.

confidence intervals for the true ORs were constructed utilising the $\log \mathrm{OR}$ and its standard error. ${ }^{13}$ Adjustment for $\mathrm{BV}$ in a stratified analysis was done using the Mantel-Haenszel procedure to provide an estimate of the pooled OR. ${ }^{13}$ Multiple logistic regression analyses were used to adjust associations between Mobiluncus or BV (dependent variables) and demographic factors or other vaginal pathogens (independent variables).$^{14}$ Odds ratios, adjusted for the independent variables, were estimated from this model by exponentiating the resulting coefficients. Approximate $95 \%$ confidence intervals were constructed using these coefficients and their standard errors.

\section{Results}

What microorganisms are independently associated with bacterial vaginosis?

As summarised in table 1, Mobiluncus was detected by Gram stain in $20 \%$ of women attending the STD clinic, including $110(53 \%)$ of those with and $16(4 \%)$ of those without a clinical diagnosis of bacterial vaginosis (unadjusted odds ratio $30,95 \%$ confidence interval 16-55). Likewise, $G$ vaginalis, $M$ hominis, $U$ urealyticum, and $N$ gonorrhoeae were positively associated with a diagnosis of $\mathrm{BV}$ by univariate analysis while facultative lactobacilli, yeast and HSV were negatively associated.

Vaginal colonisation with Mobiluncus was associated with positive vaginal cultures for $G$ vaginalis, $M$ hominis and $N$ gonorrhoeae (table 2). After adjusting for the presence or absence of bacterial vaginosis, vaginal colonisation by Mobiluncus was found to be associated with isolation of $G$ vaginalis (OR 5.6, 95\% CI 1.6, 19.5), M hominis (OR 3.7, $95 \%$ CI $2 \cdot 0,7 \cdot 0$ ) and $N$ gonorrhoeae (OR $2 \cdot 9,95 \%$ CI $1 \cdot 4$, $6.0)$ and negatively associated with isolation of yeast (OR 0.4, 95\% CI 0.2, 1.0) (table 2).

In view of the multiple associations between these infections, a logistic regression analysis was used to determine which of these organisms were independently associated with BV. The association between each organism and BV was adjusted for coinfection by each of the other organisms. As shown in table 1, Mobiluncus, $G$ vaginalis, and $M$ hominis remained strongly and independently associated with $\mathrm{BV}$, and facultative lactobacilli, yeast and HSV were negatively associated after adjustment in the multivariate analysis.

To assess the possibility that each of these associations is secondary to some other unidentified microbial pathogen or nonmicrobial correlate of BV, the relationship of Mobiluncus, $G$ vaginalis, $M$

Table 2 Microbiological correlates of Mobiluncus, adjusted for bacterial vaginosis

\begin{tabular}{|c|c|c|c|c|c|c|}
\hline \multirow[b]{2}{*}{ Organism } & \multicolumn{2}{|c|}{ Bacterial vaginosis } & \multicolumn{2}{|c|}{ No bacterial vaginosis } & \multirow[b]{2}{*}{$O R(95 \% C I)^{\star}$} & \multirow[b]{2}{*}{$p$} \\
\hline & $\begin{array}{l}\text { Mobiluncus }+ \\
n=109\end{array}$ & $\begin{array}{l}\text { Mobiluncus - } \\
n=95\end{array}$ & $\begin{array}{l}\text { Mobiluncus }+ \\
n=16\end{array}$ & $\begin{array}{l}\text { Mobiluncus - } \\
n=410\end{array}$ & & \\
\hline $\begin{array}{l}\text { G. vaginalis } \\
\text { Lactobacillus } \\
\text { Mycoplasma hominis } \\
\text { Ureaplasma urealyticum } \\
\text { Yeast } \\
\text { C. trachomatis } \\
\text { N. gonorrhoeae } \\
\text { Herpes simplex virus } \\
\text { Cytomegalovirus }\end{array}$ & $\begin{array}{r}99 \% \\
73 \% \\
89 \% \\
95 \% \\
10 \% \\
16 \% \\
23 \% \\
6 \% \\
10 \%\end{array}$ & $\begin{array}{r}95 \% \\
61 \% \\
74 \% \\
93 \% \\
15 \% \\
12 \% \\
9 \% \\
4 \% \\
10 \%\end{array}$ & $\begin{array}{r}87 \% \\
63 \% \\
69 \% \\
88 \% \\
6 \% \\
25 \% \\
19 \% \\
19 \% \\
0 \%\end{array}$ & $\begin{array}{r}57 \% \\
88 \% \\
26 \% \\
84 \% \\
24 \% \\
14 \% \\
10 \% \\
11 \% \\
5 \%\end{array}$ & $\begin{array}{l}5 \cdot 6(1 \cdot 6,19 \cdot 5) \\
1 \cdot 1(0 \cdot 6,1 \cdot 8) \\
3 \cdot 7(2 \cdot 0,7 \cdot 0) \\
1 \cdot 4(0 \cdot 6,3 \cdot 5) \\
0 \cdot 4(0 \cdot 2,1 \cdot 0) \\
1 \cdot 6(0 \cdot 8,3 \cdot 2) \\
2 \cdot 9(1 \cdot 4,6 \cdot 0) \\
1 \cdot 6(0 \cdot 7,4 \cdot 3) \\
0 \cdot 8(0 \cdot 4,2 \cdot 3)\end{array}$ & $\begin{array}{l}0.005 \\
0.67 \\
<0.001 \\
0.63 \\
0.04 \\
0.20 \\
0.004 \\
0.44 \\
0.86\end{array}$ \\
\hline
\end{tabular}

*Comparison between Mobiluncus present versus Mobiluncus absent, adjusted for bacterial vaginosis 
Table 3 Association of Mobiluncus with epidemiological characteristics, after adjusting for the presence or absence of bacterial vaginosis

\begin{tabular}{|c|c|c|c|c|c|c|}
\hline & \multicolumn{2}{|c|}{ Bacterial vaginosis } & \multicolumn{2}{|c|}{ No bacterial vaginosis } & \multirow[b]{2}{*}{$O R(95 \% C I)$} & \multirow[b]{2}{*}{$p$} \\
\hline & $\begin{array}{l}\text { Mobiluncus } \\
\text { Present } \\
n=109\end{array}$ & $\begin{array}{l}\text { Mobiluncus } \\
\text { Absent } \\
n=95\end{array}$ & $\begin{array}{l}\text { Mobiluncus } \\
\text { Present } \\
n=16\end{array}$ & $\begin{array}{l}\text { Mobiluncus } \\
\text { Absent } \\
n=410\end{array}$ & & \\
\hline $\begin{array}{l}\text { Demographic factors } \\
\text { Mean age, SD } \\
\text { Married } \\
\text { Black Race } \\
\text { Unemployed } \\
\text { Years education, SD } \\
\text { Low socioeconomic status } \\
\text { Income } \leqslant \text { US } \$ 3600\end{array}$ & $\begin{array}{l}25 \cdot 1,6 \cdot 2 \\
9 \% \\
36 \% \\
50 \% \\
12 \cdot 4,1 \cdot 7 \\
60 \% \\
58 \%\end{array}$ & $\begin{array}{l}24 \cdot 3,6 \cdot 2 \\
3 \% \\
14 \% \\
40 \% \\
12 \cdot 6,2 \cdot 1 \\
46 \% \\
47 \%\end{array}$ & $\begin{array}{l}23 \cdot 6,7 \cdot 0 \\
6 \% \\
25 \% \\
56 \% \\
13 \cdot 1,2 \cdot 5 \\
40 \% \\
60 \%\end{array}$ & $\begin{array}{l}23 \cdot 7,5 \cdot 6 \\
8 \% \\
13 \% \\
30 \% \\
13 \cdot 0,2 \cdot 3 \\
40 \% \\
44 \%\end{array}$ & $\begin{array}{l}2 \cdot 1(0 \cdot 7,6 \cdot 5) \\
2 \cdot 7(1 \cdot 5,4 \cdot 6) \\
1 \cdot 8(1 \cdot 1,2 \cdot 9) \\
\\
1 \cdot 5(0 \cdot 9,2 \cdot 6) \\
1 \cdot 6(1 \cdot 1,2 \cdot 5)\end{array}$ & $\begin{array}{c}0.32 \\
0.25 \\
<0.001 \\
0.03 \\
0.62 \\
0.15 \\
0.03\end{array}$ \\
\hline $\begin{array}{l}\text { Obstetric and gynaecological fact } \\
\text { Gravidity } \geqslant 1 \\
\text { Parity } \geqslant 1 \\
\text { Douche (ever) } \\
\text { Douche for odour }\end{array}$ & $\begin{array}{l}76 \% \\
46 \% \\
76 \% \\
12 \%\end{array}$ & $\begin{array}{r}63 \% \\
34 \% \\
75 \% \\
8 \%\end{array}$ & $\begin{array}{r}63 \% \\
31 \% \\
69 \% \\
0 \%\end{array}$ & $\begin{array}{r}53 \% \\
20 \% \\
65 \% \\
4 \%\end{array}$ & $\begin{array}{l}1 \cdot 8(1 \cdot 1,3 \cdot 1) \\
1 \cdot 7(1 \cdot 0,2 \cdot 8) \\
1 \cdot 1(0 \cdot 6,1 \cdot 9) \\
1 \cdot 3(0 \cdot 5,3 \cdot 8)\end{array}$ & $\begin{array}{l}0.04 \\
0.06 \\
0.82 \\
0.81\end{array}$ \\
\hline $\begin{array}{l}\text { Sexual history } \\
\text { Age first intercourse, SD } \\
\text { New partner in past } 30 \text { days } \\
\geqslant 15 \text { Lifetime partners } \\
\text { Uncircumcised partner }\end{array}$ & $\begin{array}{l}15 \cdot 6,2 \cdot 7 \\
38 \% \\
42 \%\end{array}$ & $\begin{array}{l}15 \cdot 0,2 \cdot 7 \\
34 \% \\
45 \%\end{array}$ & $\begin{array}{l}15 \cdot 4,3 \cdot 1 \\
13 \% \\
44 \%\end{array}$ & $\begin{array}{l}16 \cdot 5,2 \cdot 6 \\
27 \% \\
33 \%\end{array}$ & $\begin{array}{l}- \\
1 \cdot 0(0 \cdot 6-1 \cdot 8) \\
1 \cdot 0(0 \cdot 6,1 \cdot 7)\end{array}$ & $\begin{array}{l}0 \cdot 11 \\
1 \cdot 0 \\
1 \cdot 0\end{array}$ \\
\hline $\begin{array}{l}\text { Past } 30 \text { days } \\
\text { Ever }\end{array}$ & $\begin{array}{l}14 \% \\
51 \%\end{array}$ & $\begin{array}{l}15 \% \\
44 \%\end{array}$ & $\begin{array}{l}13 \% \\
25 \%\end{array}$ & $\begin{array}{r}9 \% \\
36 \%\end{array}$ & $\begin{array}{l}1 \cdot 1(0 \cdot 5,2 \cdot 4) \\
1 \cdot 1(0 \cdot 7-1 \cdot 9)\end{array}$ & $\begin{array}{l}0.93 \\
0.77\end{array}$ \\
\hline $\begin{array}{l}\text { Rectal intercourse } \\
\text { Past } 30 \text { days } \\
\text { Ever }\end{array}$ & $\begin{array}{r}8 \% \\
29 \%\end{array}$ & $\begin{array}{r}9 \% \\
42 \%\end{array}$ & $\begin{array}{r}6 \% \\
50 \%\end{array}$ & $\begin{array}{r}9 \% \\
35 \%\end{array}$ & $\begin{array}{l}0.8(0.3,1.9) \\
0.8(0.5,1.3)\end{array}$ & $\begin{array}{l}0 \cdot 70 \\
0 \cdot 40\end{array}$ \\
\hline $\begin{array}{l}\text { Current contraception } \\
\text { None } \\
\text { Oral contraceptive } \\
\text { Barrier }\end{array}$ & $\begin{array}{l}44 \% \\
26 \% \\
13 \%\end{array}$ & $\begin{array}{l}34 \% \\
30 \% \\
20 \%\end{array}$ & $\begin{array}{l}44 \% \\
25 \% \\
19 \%\end{array}$ & $\begin{array}{l}27 \% \\
39 \% \\
22 \%\end{array}$ & $0.63(0.38-1.03)$ & 0.08 \\
\hline Antibiotic past 30 days & $2 \%$ & $0 \%$ & $6 \%$ & $12 \%$ & $0.31(0.06-2 \cdot 1)$ & 0.33 \\
\hline
\end{tabular}

hominis, lactobacilli and $\mathrm{HSV}$ to $\mathrm{BV}$ was further adjusted for variables found to be associated both with $\mathrm{BV}$ and with the individual microorganisms, where $\mathrm{p}<0.1$ or OR $>2$, or $<0.6$ for both associations. The following variables which are all potential correlates of sexual exposure and behaviour were assessed for such associations: age, marital status, race, employment status, years of education, family income, gravidity, parity, history of douching, history of tampon use, age of first intercourse, new partner in the past 30 days, number of lifetime partners, history of sexual intercourse with an uncircumcised partner (ever and within one month), history of rectal intercourse (ever and within one month), current contraceptive method, and antibiotic use in the past month. All of these variables with the exception of age, marital status, tampon use, family income and rectal intercourse were associated with BV and at least one other infection. This presumably reflects the relative homogeneity of the STD clinic population with respect to these variables.

After further adjustment for these potential confounders as well as for coinfections, the following microorganisms remained positively associated with a diagnosis of bacterial vaginosis: $G$ vaginalis (OR $16 \cdot 8,95 \%$ CI 5.3, 53.4), $M$ hominis (OR 6.4, 95\% CI $3 \cdot 4,11 \cdot 8$ ) and Mobiluncus (OR 12.4, 95\% CI 5.7,
26.7), while the following microorganisms remained negatively associated with BV: facultative lactobacilli (OR 4.7, 95\% CI 0.24, 0.91), yeast (OR 0.42, 95\% CI $0 \cdot 21,0 \cdot 86$ ) and $\mathrm{HSV}$ infection (OR $0.25,95 \% \mathrm{CI}$, $0 \cdot 09,0 \cdot 68)$.

\section{Is Mobiluncus colonisation correlated with clinical symptoms or signs?}

As noted above, Mobiluncus was strongly associated with the clinical criteria for BV. However, among women with $\mathrm{BV}$, those colonised with Mobiluncus were no more likely than those not colonised to complain of odour ( $52 \%$ vs $59 \%$ ), prolonged menstrual bleeding ( $14 \%$ vs $14 \%$ ), increased menstrual bleeding ( $13 \%$ vs $13 \%)$, abdominal pain ( $43 \%$ vs $37 \%$ ), or to have signs of yellow discharge ( $55 \%$ vs $55 \%$ ) or adnexal tenderness ( $4 \%$ vs $4 \%$ ). Likewise those women with Mobiluncus were as likely as those without to have more than 30 polymorphonuclear leukocytes per high power field in the vaginal wet mount or Gram stained endocervical smear.

Are there risks factors or risk markers for vaginal colonisation by Mobiluncus?

After adjusting for BV, colonisation with Mobiluncus was associated with black race and lack of employment and low income, but not with educational status (table 3). Of the gynaecological 
and obstetric factors investigated, gravidity and parity were associated with colonisation by $\mathrm{Mobi}$ luncus after stratifying for BV. Among women with BV, colonisation with Mobiluncus was associated with past infection with $N$ gonorrhoeae ( $41 \%$ vs $27 \%$, $\mathrm{p}=0.06$ ) but not with past infection with any other STD pathogen or syndrome.

Women harbouring Mobiluncus tended toward an earlier age at first intercourse, but were no more likely to have had a new sexual partner in the past month, to have had sexual intercourse with an uncircumcised partner, or to have had rectal intercourse. Contraceptive use was less common among those women colonised with Mobiluncus, and these women were less likely to use barrier or oral contraceptives, although these relationships were not statistically significant.

\section{Discussion}

The vaginal microflora of women with bacterial vaginosis is characterised by decreased prevalence and concentration of lactobacilli and an increased prevalence of Gardnerella, anaerobic rods and cocci $^{111^{16}}$ and Mycoplasma hominis. ${ }^{117}{ }^{17} \mathrm{Krohn}$ et al reported that $G$ vaginalis, $M$ hominis and Bacteroides species were independently associated with a clinical diagnosis of BV among 593 pregnant women. Martius $e t a l^{12}$ in a case-control study of women in preterm labour, showed that Mobiluncus spp, $G$ vaginalis, Bacteroides melaninogenicus and $M$ hominis were independently associated with $\mathrm{BV}$ as diagnosed by vaginal Gram smear. Like Krohn and Martius, we found that Lactobacillus were significantly less often recovered from women with $\mathrm{BV}$ after adjusting for other microorganisms. The current study also suggests that lower genital tract yeast and herpes simplex virus are negatively associated with $\mathrm{BV}$, and that cervical $N$ gonorrhoeae is positively associated with $B V$. Cristiano et $a^{\beta}$ have reported that vaginal yeasts are negatively associated with bacterial vaginosis and that $C$ trachomatis was positively associated with bacterial vaginosis $(5 \%$ vs $1 \%$, OR $6 \cdot 7,95 \%$ CI $2 \cdot 5$, 18). We did not find a relationship between bacterial vaginosis and cervical $C$ trachomatis.

Thomason et $a l^{10}$ found that women with motile curved rods on vaginal wet mount were more likely to be colonised with Gardnerella, Bacteroides and Peptostreptococcus, but only 40 women were studied and sexually transmitted disease pathogens were not recovered. We did not analyse the association of Mobiluncus with other anaerobes in this study.

We found that while Mobiluncus was strongly associated with clinical criteria for BV there was no indication that vaginal Mobiluncus was associated with particular symptoms or signs among women with BV. Larsson and Bergman ${ }^{18}$ reported that thirteen women with intermenstrual bleeding or spotting of 1 to 12 months duration were positive for Mobiluncus by vaginal wet mount. After treatment with metronidazole and the disappearance of Mobiluncus, the irregular bleeding episodes stopped. In the present study, we found no association of Mobiluncus with increased or prolonged menstrual bleeding or increased intermenstrual bleeding.

The association of Mobiluncus with black race, unemployment, and low income suggests the need to assess further the role of behaviour or risk factors among low socioeconomic status women as risk factors for colonisation by Mobiluncus. The association of Mobiluncus with present and past infection by $N$ gonorrhoeae after adjusting for $\mathrm{BV}$ suggest a common epidemiology for these two organisms. Others have reported that Mobiluncus can be recovered from up to $53 \%$ of the rectal specimens from women with bacterial vaginosis. ${ }^{19}$ We were unable to detect an association between Mobiluncus and recent or past rectal intercourse, or recent or past vaginal intercourse with an uncircumcised partner.

In this study Mobiluncus was detected by examining a Gram stained vaginal smear for characteristic curved rod morphotypes. While direct vaginal Gram stain is a relatively insensitive method for detection of any microorganism, most attempts to isolate Mobiluncus from the vagina suggest culture remains insensitive. $\mathrm{Hjelm}^{20}$ isolated the organism from 10 of 17 vaginal specimens in which motile rods were seen by wet mount. Spiegel $e t \mathrm{al}^{2}$ isolated the organism from only 6 of 31 vaginal specimens whose Gram stains showed curved rods, while Thomason et $a l^{10}$ isolated motile curved rods from 5 of 21 women who had motile curved forms in the wet smears of their vaginal fluid. Pahlson et $a l^{21}$ were able to recover Mobiluncus from $70 \%$ of the vaginal samples positive for Mobiluncus by direct monoclonal antibody staining, even after using an elaborate dilution technique for culture. Methods employing cold enrichment, ${ }^{22}$ selective media or alkaline treatment ${ }^{23}$ have not proved optimal for Mobiluncus. Thus, in this study we chose to detect Mobiluncus by examination of Gram stained vaginal smears, a method we found to be reproducible and specific, despite the limits in sensitivity.

In summary, Mobiluncus, $G$ vaginalis and $M$ hominis are independently associated with bacterial vaginosis. Among women with BV, Mobiluncus is not associated with unique clinical manifestations. This cross-sectional study suggests a possible relationship of low SES for vaginal colonisation by Mobiluncus, a relationship that warrants further study.

This study was supported in part by NIH Grants AI19192 from the National Institute of Allergy \& Infectious Diseases, and CA34493 from the National Cancer Institute. 
Address for correspondence: Dr Sharon Hillier, Department of Obstetrics and Gynecology, RH-20, University of Washington, Seattle, WA 98195, USA.

1 Spiegel CA, Roberts M. Mobiluncus gen nov, Mobiluncus curtisii subsp curtisii sp nov, Mobiluncus curtisii subsp holmesii subsp nov, and Mobiluncus mulieris sp nov, curved rods from the human vagina. Int $J$ Syst Bacteriol 1984;34:177-84.

2 Spiegel CA, Eschenbach DA, Amsel RA, Holmes KK. Curved anaerobic bacteria in bacterial (nonspecific) vaginosis and their response to antimicrobial therapy. $J$ Infect Dis 1983;148:817-22.

3 Cristiano L, Coffetti N, Dalavai G, Lorusso L, Lorenzi M. Bacterial vaginosis: prevalence in outpatients, association with some microorganisms and laboratory indices. Genitourin Med 1989;65:382-7.

4 Hallen A, Pahlson C, Forsum V. Bacterial vaginosis in women attending STD clinic: diagnostic criteria and prevalence of Mobiluncus spp. Genitourin Med 1987;63:386-9.

5 Roberts MC, Hillier SL, Schoenknecht FD, Holmes KK. Comparison of Gram stain, DNA probe, and culture for the identification of species of Mobiluncus in the female genital tract. J Infect Dis 1985;152:74-7.

6 Krohn MA, Hillier SL, Eschenbach DA. Comparison of methods for diagnosing bacterial vaginosis among pregnant women. J Clin Microbiol 1989;27:1266-71.

7 Amsel R, Totter PA, Spiegel CA, Chen KCS, Eschenbach DA, Holmes KK. Non specific vaginitis: diagnostic criteria and microbial and epidemiologic associations. Am J Med 1983; 74:14-22.

8 Spiegel CA, Amsel R, Holmes KK. Diagnosis of bacterial vaginosis by direct $\mathrm{Gram}$ stain of vaginal fluid. J Clin Microbiol 1983;18:170-7.

9 Eschenbach DA, Hillier SL, Critchlow C, Stevens C, De Rouen T, Holmes KK. Diagnosis and clinical manifestations of bacterial vaginosis. Am J Obstet Gynecol 1988;158:819-28.

10 Thomason JL, Schreckenberger PC, Spellacy WN, Riff LJ,
LeBeau LJ. Clinical and microbiological characterization of patients with nonspecific vaginosis associated with motile, curved rods. J Infect Dis 1984;149:801-9.

11 Holst E, Wathre B, Hovelius B, Mardh PA. Bacterial vaginosis: microbiological and clinical findings. Eur J Clin Microbiol 1987;6:536-41.

12 Martius J, Krohn MA, Hillier SL, Stamm WE, Holmes KK. Relationship of vaginal Lactobacillus species, cervical Chlamydia trachomatis, and bacterial vaginosis to preterm birth. Obstet Gynecol 1988;71:89-95.

13 Fleiss JL. Statistical Methods for Rates and Proportions. 2nd ed. New York: John Wiley, 1981:90.

14 Breslow NE, Day NE. Statistical Methods in Cancer Research. Vol 1. The Analysis of Case-control Studies. Lyon, France: International Agency for Research on Cancer, 1980.

15 Spiegel CA, Amsel R, Eschenbach D, Schoenknecht F, Holmes $\mathrm{KK}$. Anaerobic bacteria in nonspecific vaginitis. $N$ Engl J Med 1980;303:601 -7.

16 Piot P, Van Dyck E, Godts P, Vanderheyden J. The vaginal microbial flora in non-specific vaginitis. Eur J Clin Microbiol 1982;1:301-6.

17 Paavonen J, Miettinen A, Stevens CE, Chen KC, Holmes KK. Mycoplasma hominis in nonspecific vaginitis. Sex Transm Dis 1983;10:271-5.

18 Larsson PG, Bergman BB. Is there a caused connection between motile curved rods, Mobiluncus species, and bleeding complications? Am J Obstet Gynecol 1986;154:107-8.

19 Hallen A, Pahlson C, Forum V. Rectal occurrence of Mobiluncus. Genitourin Med 1988;64:273-5.

$20 \mathrm{Hjelm}$ E, Hallen A, Forsum U, Wallin J. Anaerobic curved rods in vaginitis. Lancet $1981 ;$ ii: $1353-4$.

21 Pahlson C, Hallen A, Forsum U. Curved rods related to Mobiluncus-phenotypes as defined by monoclonal antibodies. Acta Path Microbiol Immunol Scand Sect B 1986;94:117-25.

22 Smith HJ, Moore HB. Isolation of Mobiluncus species from clinical specimens by using cold enrichment and selective media. J Clin Microbiol 1988;26:1134-7.

23 Pahlson C, Hallen A, Forsum U. Improved yield of Mobiluncus species from clinical specimens after alkaline treatment. Acta Pathol Microbiol Immunol Scand Sect B 1986;94:113-6.

Accepted for publication 11 September 1990 